Berger, J. A. \& MARr, A. G. (1960). J. gen. Microbiol. 22, 147-157

\title{
Sonic Disruption of Spores of Bacillus cereus
}

\author{
BY JOYCE A. BERGER AND A. G. MARR \\ Department of Bacteriology, University of Califormia, Davis, Califormia, U.S.A.
}

SUMMARY: The sonic disruption of spores of Bacillus cereus gives multi-hit kinetics. The first hit destroys the exosporium, which protects the spore body from destruction; the second hit destroys the spore body. Spores which have been stripped of their exosporia are still viable and heat resistant. From the rate of release during sonic treatment it appears that alanine racemase, adenosine deaminase and hexosamine are located in the exosporium while ribosidase is in the spore body. The rate of release of dipicolinic acid does not identify its location.

Since the discovery of alanine racemase in spores (Stewart \& Halvorson, 1953) several other enzymes have been found in preparations of well-cleaned spores (reviewed by Halvorson \& Church, 1957). Many of the enzymes in extracts of spores are particulate and heat-stable, but the location of the enzymes within the spore is somewhat obscure. Electron micrographs of thin sections of spores of Bacillus cereus (Robinow, 1953) show a large well-defined exosporium as the outermost structure surrounding the spore coat. The electrondense spore coat, in turn, delimits what we shall refer to as the spore body. The particulate enzymes of the spore could be contained within the spore body or could be submicroscopic fragments of the spore coat or of the exosporium. A decision between similar alternatives in Azotobacter vinelandii has been made by measuring the rates of release of constituents during sonic disruption (Marr \& Cota-Robles, 1957). Submicroscopic particles and soluble constituents of the cytoplasm were released at the same rate as the disruption of the cell, while submicroscopic particles derived by disintegration of the envelope were released more slowly. In the application of this technique of differential release to the biochemical cytology of spores we were somewhat surprised to find that several constituents of the spore are released more rapidly than the rate of disruption of the spore body. These constituents appear to be in the exosporium.

\section{METHODS}

Organism and cultural methods. Bacillus cereus 2005 was obtained from the collection of lyophilized cultures maintained by the Department of Bacteriology, University of California. B. cereus var. terminalis was obtained from Dr H. O. Halvorson. Both were cultivated on medium ' $G$ ' of Stewart \& Halvorson (1958) which has the following composition per litre of solution: $\mathrm{K}_{2} \mathrm{HPO}_{4}, 1 \mathrm{~g}$.; $\left(\mathrm{NH}_{4}\right)_{2} \mathrm{SO}_{4}, 4$ g.; yeast extract, $2 \mathrm{~g}$.; $\mathrm{MnSO}_{4} . \mathrm{H}_{2} \mathrm{O}, 0.1 \mathrm{~g}$.; $\mathrm{MgSO}_{4} .7 \mathrm{H}_{2} \mathrm{O}, 0 \cdot 8 \mathrm{~g}$.; $\mathrm{ZnSO}_{4} .7 \mathrm{H}_{2} \mathrm{O}, 10 \mathrm{mg}$; $\mathrm{CuSO}_{4} .5 \mathrm{H}_{2} \mathrm{O}, 10 \mathrm{mg}$; $\mathrm{CaCl}_{2}, 10 \mathrm{mg}$; $\mathrm{FeSO}_{4} \cdot 7 \mathrm{H}_{2} \mathrm{O}$, $1.0 \mathrm{mg}$; glucose, $4 \mathrm{~g}$. One litre of this medium in a 21 . Fernbach flask was autoclaved at $121^{\circ}$ for $15 \mathrm{~min}$. Each flask was inoculated with $1 \mathrm{ml}$. of a liquid culture containing spores which had been heat-shocked at $67^{\circ}$ for 
$15 \mathrm{~min}$. The flasks were incubated at $28^{\circ}$ on a shaker until spores were formed and all the sporangia had disintegrated; this was usually 3 or 4 days for $B$. cereus 2005 and 2 days for $B$. cereus var. terminalis.

Spores were harvested in a Sharples centrifuge and washed 6-10 times with distilled water or phosphate buffer until microscopic examination indicated the absence of debris from vegetative cells. The spores were suspended in $0.05 \mathrm{M}$-phosphate buffer ( $\mathrm{pH} \mathrm{6.8}$ ) to a concentration of $3 \times 10^{9} \mathrm{spores} / \mathrm{ml}$. with less than $5 \%$ germinated spores.

Sonic dismuption. Of the above spore suspension $50 \mathrm{ml}$. were treated at 75 acoustical watts in a Raytheon $10 \mathrm{kc}$. sonic oscillator at $0^{\circ}-3^{\circ}$ and in a gas atmosphere of $\mathrm{H}_{2}$. At various times, 3 or $5 \mathrm{ml}$. samples were removed and were replaced by an equal volume of buffer. Corrections were made for the progressive dilution resulting from this sampling. Release of constituents was determined by centrifuging partions of the samples at $10,000 . \mathrm{g}$ for $15 \mathrm{~min}$., which was sufficient to sediment residual spores and fragments of microscopic dimensions. Release was judged by failure to sediment in this centrifugation. All assays except that for deaminase were made on the residue.

Turbidity was measured in a Klett colorimeter with a red filter.

Counting. Intact spores were counted in a haemocytometer with plane surfaces using a $4 \mathrm{~mm}$. phase-contrast objective (Zeiss Ph 2 neofluar). At least 400 spores were counted. The fraction of spores with exosporia was estimated by differential count of a wet mount with a $1.8 \mathrm{~mm}$. phase-contrast objective (Zeiss $\mathrm{Ph} 3$ neofluar) with a $\times 15$ compensating ocular; at least 200 spores were counted. Viable spores were counted by spreading samples on the surface of nutrient agar.

Microscopy. Photographs were made of air dried spores on formvar with an RCA EMU-3 electron microscope at $100 \mathrm{kV}$.

Alanine racemase. One $\mathrm{ml}$. of sample and $2.0 \mathrm{ml}$. of $0.05 \mathrm{M}$-Tris buffer (tris [hydroxymethyl] aminomethane chloride; $\mathrm{pH} \mathrm{8.2-8 \cdot 3)}$ were added to $18 \mathrm{~mm}$. tubes and allowed to stand for $15 \mathrm{~min}$. in a water bath at $37^{\circ}$. One ml. of $0.8 \mathrm{M}-\mathrm{L}-$ alanine was added to the tubes and the contents thoroughly mixed. After $\mathbf{3 0} \mathrm{min}$. the reaction was stopped by the addition of $1.0 \mathrm{ml}$. $\mathrm{N}-\mathrm{H}_{2} \mathrm{SO}_{4}$. The tubes were placed in boiling water for $15 \mathrm{~min}$. to coagulate protein. After cooling, 1.0 g. Amberlite IR 4B (OH) resin was added to neutralize the acid. One to $1.5 \mathrm{ml}$. samples were analysed for D-alanine with D-amino acid oxidase, purified according to the method of Negelein \& Brömel (1988) including the second precipitation with ammonium sulphate. For the assay of D-alanine formed during racemization, $1.5 \mathrm{ml}$. of the sample and $0.5 \mathrm{ml}$. of $0.2 \mathrm{M}$-tris buffer ( $\mathrm{pH}$ 8.2) were added to the main compartment of a Warburg flask, and $1.0 \mathrm{ml}$. of D-amino acid oxidase solution was added to the side arm. After equilibration the contents of the side arm were added to the main compartment and the oxygen uptake recorded until the reaction ceased. One $\mu$ mole oxygen was equivalent to $2 \mu$ mole $D$-alanine since the preparation of oxidase contained excess catalase. One unit of alanine racemase was defined as the amount of enzyme required to produce $1 \mu$ mole $\mathrm{D}$-alanine in $30 \mathrm{~min}$.

Adenosine deaminase. Before assay the samples were dialysed against 
$0.01 \mathrm{~m}$-Tris buffer ( $\mathrm{pH} \mathrm{8.2)} \mathrm{for} 18 \mathrm{hr}$. to remove most of the dipicolinic acid (DPA). Adenosine deaminase activity was then determined spectrophotometrically by following the decrease in absorbance at $265 \mathrm{~m} \mu$. The Beckman spectrophotometer was set at zero with a control consisting of $2.0 \mathrm{ml} .0 .05 \mathrm{M}$ Tris (pH 8.2) and either $1.0 \mathrm{ml}$. of the dialysed supernatant liquid or a solution of adenosine which had the same absorbance. The experimental cuvette contained $1.8 \mathrm{ml}$. $0.05 \mathrm{M}$-Tris at $\mathrm{pH} 8.2$ and $0.20 \mathrm{ml} .6 \times 10^{-4} \mathrm{M}$-adenosine was added to start the reaction. The change in absorbance at $265 \mathrm{~m} \mu$ was measured at intervals of $1 \mathrm{~min}$. The rate of deamination was determined from the linear portion of the plot of absorbance against time. One unit of deaminase was taken as the amount of enzyme required to change the absorbance 0.001 unit/ min.

Ribosidase. To each of three $15 \mathrm{~mm}$. tubes, $1.0 \mathrm{ml}$. of the sample and $1.0 \mathrm{ml}$. of 0.05 M-phosphate buffer was added. One ml. water was added to the blank control and $1.0 \mathrm{ml} .6 \times 10^{-4} \mathrm{M}$-adenosine was added to the experimental tube. The three tubes were incubated at $37^{\circ}$ for $90 \mathrm{~min}$. At this time $1.0 \mathrm{ml}$. of the adenosine solution was added to the third tube (zero control). Protein was precipitated by adding $0.1 \mathrm{ml}$. saturated $\mathrm{Ba}(\mathrm{OH})_{2}$ and $0.1 \mathrm{ml} . \mathrm{ZnSO}_{4}$ to all three tubes. The concentration of $\mathrm{ZnSO}_{4}$ was adjusted such that the final $\mathrm{pH}$ was 8. After the addition of $5.0 \mathrm{ml}$. distilled water, the tubes were centrifuged at $5000 \mathrm{~g}$ for $10 \mathrm{~min}$. to remove the precipitated protein. The supernatant liquid was decanted and acidified with one drop of $6 \mathrm{~N}-\mathrm{H}_{2} \mathrm{SO}_{4}$. The samples were shaken with $1.0 \mathrm{~g}$. Amberlite IRC-120 resin to remove residual adenosine. To $3.0 \mathrm{ml}$. of the supernatant fluids were added $3.0 \mathrm{ml} .0 .048 \%(\mathrm{w} / \mathrm{v}) \mathrm{FeCl}_{3}$ in concentrated $\mathrm{HCl}$ and $0.3 \mathrm{ml} .0 \cdot 1 \%(\mathrm{w} / \mathrm{v})$ orcinol in absolute ethanol. The contents of the tubes were mixed; the tubes were covered with glass marbles and placed in a boiling water bath for $45 \mathrm{~min}$. After cooling, the absorbance at $660 \mathrm{~m} \mu$ was measured against the blank control. Ribose was estimated from a standard curve obtained with known concentrations of ribose. The amount of ribose formed during the enzymic reaction was calculated from the difference between the experimental tube and the zero-time control. One unit of ribosidase was defined as that amount of enzyme required to release one $\mu$ mole ribose.

Hexosamine. Samples were made $1 \mathrm{~N}$ with $\mathrm{HCl}$ and were autoclaved in sealed ampoules at $121^{\circ}$ for $1 \mathrm{hr}$. The hydrolysed samples were dried over $\mathrm{NaOH}$ in vacuo to remove $\mathrm{HCl}$, then made to their original volumes with distilled water. Undissolved material was removed by centrifugation at $10,000 \mathrm{~g}$ for $15 \mathrm{~min}$. One $\mathrm{ml}$. samples were analysed for hexosamine by a modification (Berger \& Reynolds, 1958) of the Morgan \& Elson reaction, using standards of hexosamine $\mathrm{HCl}$.

Dipicolinic acid (DPA). Dipicolinic acid was estimated spectrophotometrically after acid hydrolysis (see section on hexosamine). The absorbance of the sample at $270 \mathrm{~m} \mu$ was used as a measure of the relative amount of DPA present in the hydrolysed samples. No correction was made for the small contribution of purines, pyrimidines and other substances. 


\section{RESULTS}

\section{Kinetics of sonic dismuption}

During a survey of the sensitivity of various micro-organisms to sound we discovered that the kinetics of disruption of spores of Bacillus cereus differed from the simple first-order kinetics of sonic disruption of other cells. Figure 1 shows the rate of change of direct count and turbidity; both are plotted as the logarithm of $\%$ initial value. If a single interaction between the spore and the sound field were sufficient to disrupt the spore, the plot would be linear from the beginning of treatment with an ordinate intercept at 2.0 $(100 \%)$. In this experiment there was a lag of $c .45 \mathrm{~min}$. before the disruption of spores was measurable. After the lag turbidity and direct count both appear to decrease exponentially.

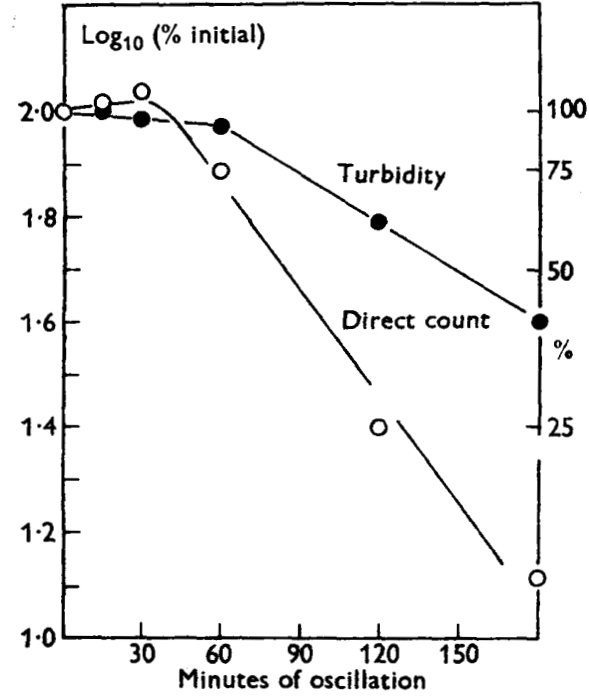

Fig. 1

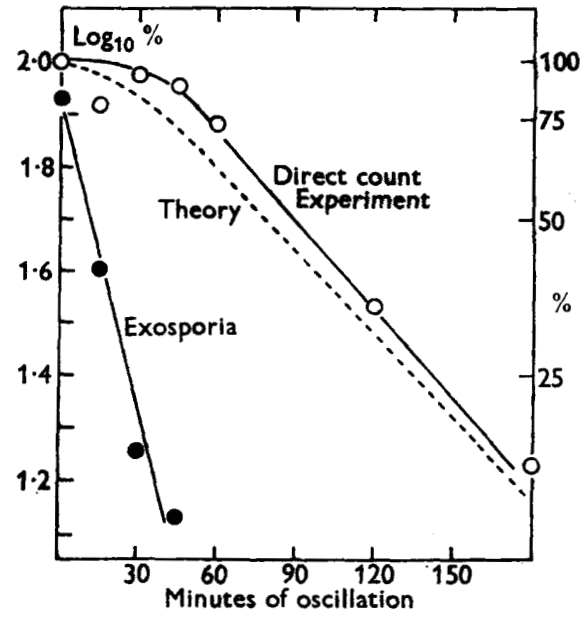

Fig. 2

Fig. 1. Decrease in turbidity and direct count during sonic treatment of spores of Bacillus cereus 2005. Fifty ml. of a suspension containing c. $3 \times 10^{\circ} \mathrm{spores} / \mathrm{ml}$. were treated for the times indicated at approximately 75 acoustical watts.

Fig. 2. Rate of loss of exosporia and of decrease in direct count of spores of Bacillus cereus 2005. The \% spores with exosporia was determined by differential count and logarithm of the \% plotted. The first-order rate constant was estimated from the slope of this plot to be $0.045 \mathrm{~min}$. $^{-1}$. The first-order rate constant for the destruction of spores was estimated to be $0.0127 \mathrm{~min} .^{-1}$ from the slope of the plot of direct count between 60 and $150 \mathrm{~min}$. The dashed curve is the theoretical number of intact spores computed from the equation for two consecutive first-order reactions:

$$
y=\frac{k_{2} e^{-k_{1} t}-k_{1} e^{-k_{2} t}}{k_{2}-k_{1}}
$$

where $y$ is the number of intact spores, $k_{1}$ the first-order rate constant for the stripping of exosporia, $k_{2}$ the first-order rate constant for the destruction of spores, and $t$ the time in min. 
The microscopic appearance of the spores shows a striking correlation with the lag phase. Plate 1 shows the change in appearance of spores of Bacillus cereus 2005 during sonic treatment; the untreated spore is surrounded by a distinct exosporium; after $1 \mathrm{hr}$. most of the exosporia have been lost and only a few remnants of the exosporium are still evident. Suspensions of stripped spores agglutinate more readily than suspensions of normal spores, reflecting the change in the surface.

It appears that the exosporium protects the spore from disruption until the exosporium itself has been destroyed. The first interaction with the sound field destroys the exosporium and the second destroys the spore. Figure 2 is a plot of spores with exosporia and of total intact spores. The loss of the exosporium is first order with a rate constant of $0.045 \mathrm{~min}^{-1}$. A firstorder rate constant for the disruption of spores was estimated from the linear portion of the plot of direct count to be $0.0127 \mathrm{~min}^{-1}$. As a test of the hypothesis that the loss of the exosporium necessarily precedes the disruption of the spore, we have computed the theoretical curve (dashed line in Fig. 2) for the change in direct count based on two sequential first-order reactions, the first with a rate constant of $0.045 \mathrm{~min}^{-1}$ and the second with a rate constant of $0.0127 \mathrm{~min} .^{-1}$. The agreement between the predicted curve and the experimental results is satisfactory.

\begin{tabular}{|c|c|c|c|}
\hline \multirow{2}{*}{$\begin{array}{l}\text { Time of } \\
\text { treatment } \\
\text { (min.) }\end{array}$} & \multirow[b]{2}{*}{$\begin{array}{c}\text { Direct count } \\
\left(\times 10^{-9}\right)\end{array}$} & \multicolumn{2}{|c|}{ Viable count $\left(\times 10^{-9}\right)$} \\
\hline & & $\begin{array}{c}\text { Before } \\
\text { heating }\end{array}$ & $\begin{array}{c}\text { After } \\
\text { heating }\end{array}$ \\
\hline 0 & $3 \cdot 6$ & $2 \cdot 7$ & $2 \cdot 9$ \\
\hline 15 & $4 \cdot 2$ & 3.9 & 3.4 \\
\hline 30 & $5 \cdot 4$ & $5 \cdot 9$ & 3.3 \\
\hline 60 & $5 \cdot 6$ & $6 \cdot 3$ & $4 \cdot 4$ \\
\hline
\end{tabular}

The effect of removal of the exosporium on viability is illustrated in Table 1 . During the first hour of treatment neither the direct nor viable counts decreased; in most trials the counts were increased by the disruption of a few large clumps of spores. The spores retained their resistance to the standard heat-shock treatment after removal of the exosporium. A more detailed analysis of the role of the exosporium in heating has recently been made by Mr R. N. Getchell, who has followed the kinetics of thermal inactivation of stripped and normal spores of Bacillus cereus 2005 at several temperatures. He has observed a slight increase in the rate of killing of spores from which the exosporium has been sonically removed; however, the ' $Z$-values', the change of rate with change in temperature, between $65^{\circ}$ and $82^{\circ}$, was identical.

If the exosporium functions biochemically in the germination of spores, one might expect an increase in the minimum requirements for germination; however, the spores devoid of an exosporium show over $95 \%$ germination after $1 \mathrm{hr}$. in a mixture of $6.7 \times 10^{-3} \mathrm{M}-\mathrm{L}$-alanine and $1.2 \times 10^{-5} \mathrm{M}$-adenosine 
in $0.067 \mathrm{M}$-pyrophosphate buffer which represent the minimum nutritional requirements for germination of the untreated spores.

The sonic disruption of Bacillus cereus var. terminalis is shown in Fig. 3. The rate of removal of the exosporium is $0.04 \mathrm{~min} .^{-1}$, which is quite similar to that of $B$. cereus 2005; the rate of disruption of the spore body, however, is less than $0.003 \mathrm{~min}^{-1}$ which is much lower than the rate of disruption of spores of $B$. cereus 2005. Plate 2 shows the appearance of the spores of $B$. cereus var. terminalis before and after $2 \mathrm{hr}$. of sonic treatment, illustrating the removal of the exosporium by sonic treatment.

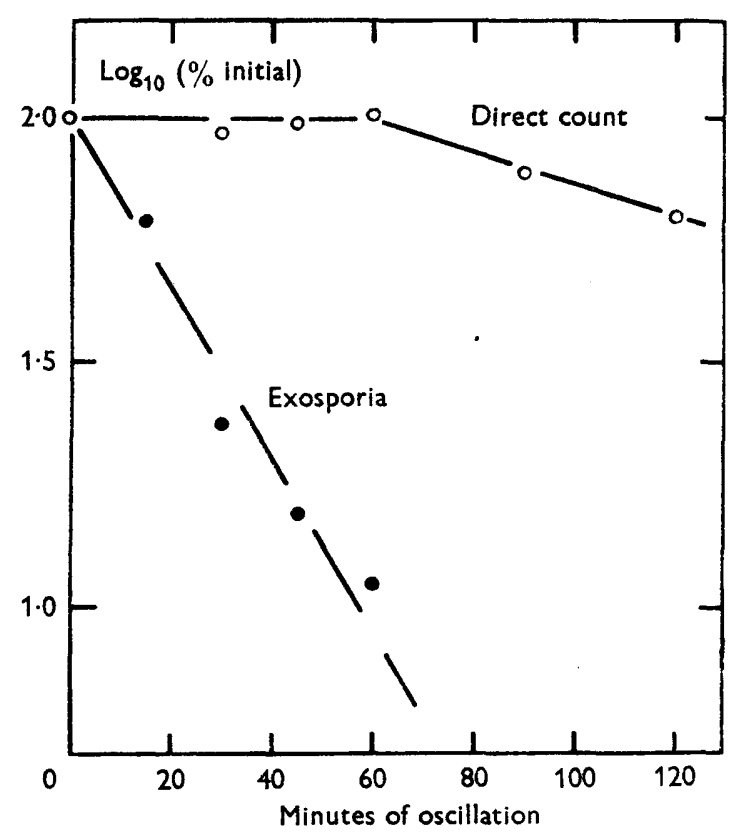

Fig. 8. Rate of loss of exosporia and of decrease in direct count of spores of Bacillus cereus var. terminalis.

\section{Release of constituents}

The separation in time of the loss of the exosporium and of the disruption of the stripped spores permits a simple determination of the location of various constituents of the spore. If a substance is in the exosporium, it should be released from the spores without a lag and at the same rate as the loss of exosporia. If a substance is in the spore body, it should be released only after a lag. The location of alanine racemase, adenosine deaminase, ribosidase, hexosamine and dipicolinic acid (DPA) were tested on this basis.

Figure 4 shows the release of substances which appear to be located in the exosporium of Bacillus cereus 2005. The criterion of release from the spores was failure to sediment at $10,000 \mathrm{~g}$ in $15 \mathrm{~min}$., which is sufficient to sediment the intact spores. The residues were resuspended in $0.05 \mathrm{M}$-phosphate (pH 6.8). Racemase and hexosamine were determined in the residue; deaminase was 
determined in the supernatant liquid. The values plotted are the logarithms of $\%$ of the substance still sedimenting with the spores. Hexosamine, racemase and deaminase were all released exponentially and without a lag at a rate identical with the rate of stripping of the exosporia.

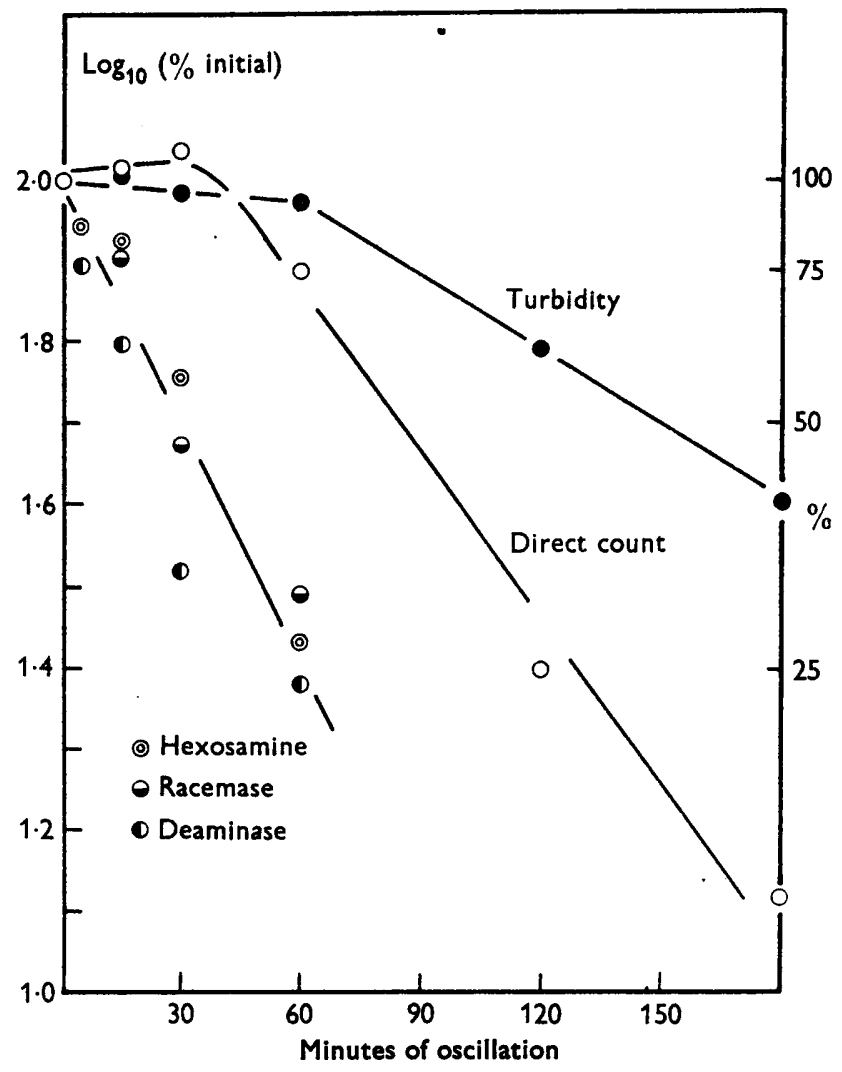

Fig. 4. The release of hexosamine, deaminase and racemase during sonic treatment of spores of Bacillus cereus. The data are from the same experiment as Fig. 1. The values plotted are the logarithm of the $\%$ of the total which sediment with the spores after centrifuging at $10,000 \mathrm{~g}$ for $15 \mathrm{~min}$. The initial spore concentration was $3 \times 10^{\circ} / \mathrm{ml}$.; total racemase, 186 units/ml.; total deaminase, 17 units $/ \mathrm{ml}$.; total hexosamine, $270 \mu \mathrm{g} . / \mathrm{ml}$.

Figure 5 shows the release of ribosidase and DPA which were measured in the residue from centrifugation at $10,000 \mathrm{~g}$. The release of ribosidase was identical with the rate of disruption of the spores, indicating that ribosidase is located in the spore body. The release of DPA was also exponential and without a lag; however, the rate of release of DPA was less than the rate of stripping of the exosporium. Thus, DPA cannot be exclusively in the exosporium. Either there are two pools of DPA or the release is independent of visible mechanical damage of the spore by sonic treatment. 


\section{Physical state of components in spore extracts}

After different times of sonic treatment of a suspension of spores of Bacillus cereus 2005, samples were centrifuged to remove spores and centrifuged again at $100,000 \mathrm{~g}$ for $1 \mathrm{hr}$. The residue and supernatant fluid from this last centrifugation were assayed for deaminase, racemase, hexosamine and DPA. The results of one such experiment are given in Table 2. After sonic treatment

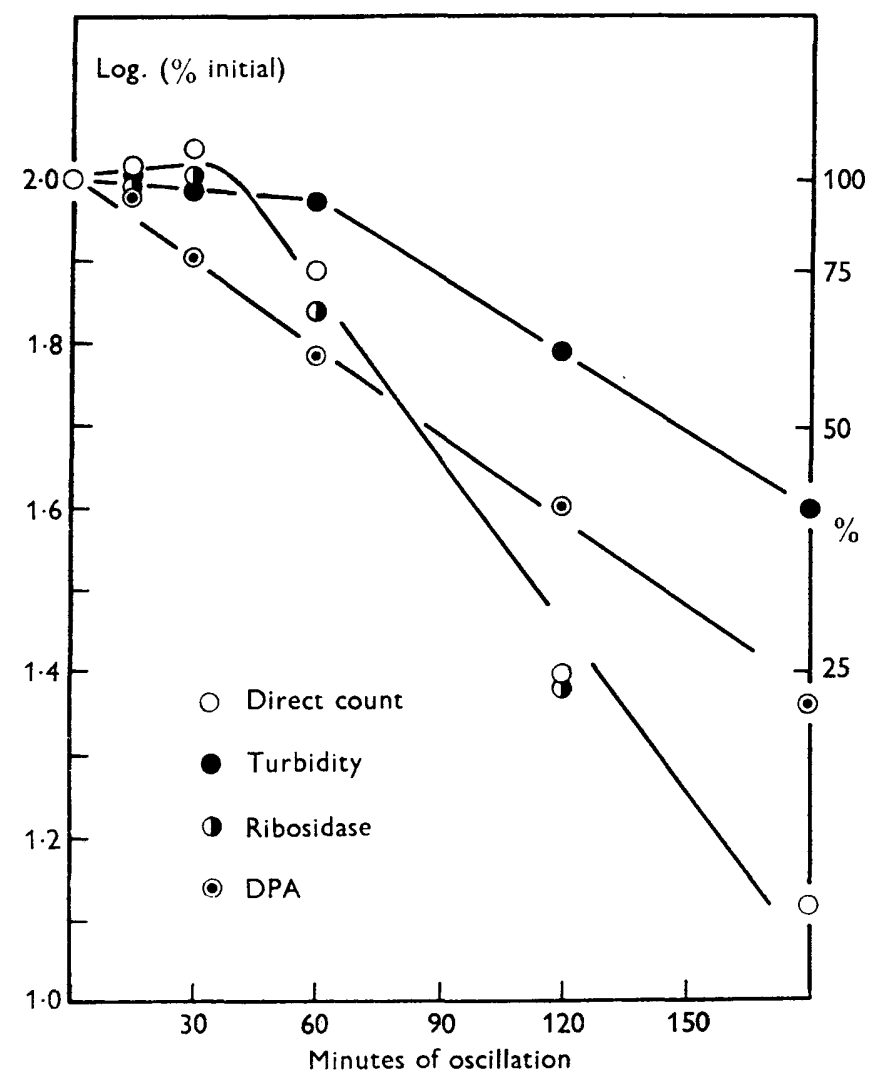

Fig. 5. The release of ribosidase and DPA during the sonic treatment of spores of $B$. cereus 2005. The data are from the same experiment as Fig. 1. The values plotted are the logarithm of the \% of the total which sediments with the spores after centrifuging at $10,000 \mathrm{~g}$ for $15 \mathrm{~min}$. Initial spore concentration $3 \times 10 \% \mathrm{ml}$; total ribosidase 0.042 unit/ml.

for 30 min., half or more of each constituent was sedimented. After longer sonic treatment most of the hexosamine and DPA and a considerably larger fraction of the racemase and deaminase were soluble as defined by their failure to sediment. These results suggest that none of the four components is soluble in the spore. Concomitant with the solubilization was a loss of heat resistance. Heating the particulate fraction for $15 \mathrm{~min}$. at $65^{\circ}$ inactivated 
less than $5 \%$ of the deaminase and racemase. Heating the soluble fraction destroyed almost all of the deaminase and a measurable quantity of the racemase; however, the racemase was resistant to heating even after solubilization.

Table 2. Distribution of components between particulate and soluble

$$
\text { fractions of spore extracts }
$$

Samples of the suspension of spores of Bacillus cereus 2005 after 30 min. and 210 min. of sonic treatment were centrifuged to remove the residual spores, and the supernatant fluid centrifuged at $100,000 \mathrm{~g}$ for $1 \mathrm{hr}$. Material not sedimented by this treatment is arbitrarily referred to as soluble. The heat stability of the soluble fraction was tested by heating a sample to $65^{\circ}$ for $15 \mathrm{~min}$. The values are in $\%$ of the total.

\begin{tabular}{|c|c|c|c|c|}
\hline & Deaminase & Racemase & Hexosamine & DPA \\
\hline $\begin{array}{l}30 \mathrm{~min} . \\
\text { Total released }\end{array}$ & & & & \\
\hline Soluble & 20 & 4 & 15 & 20 \\
\hline $\begin{array}{l}\text { Soluble, heated } \\
210 \text { min. }\end{array}$ & 6 & $\mathbf{3}$ & - & \\
\hline Total released & 90 & 90 & 86 & \\
\hline Soluble & $\mathbf{5 0}$ & $\mathbf{5 9}$ & 77 & \\
\hline Soluble, heated & $\mathbf{0}$ & 40 & - & \\
\hline
\end{tabular}

\section{DISCUSSION}

The exosporium, which is a prominent structure in electron micrographs of whole spores (Robinow, 1951) and thin sections (Robinow, 1953) of the spores of Bacillus cereus, has often been confused with the sporangium. We have shown in this study that the exosporium is the probable site of alanine racemase, adenosine deaminase and hexosamine, which are thought to be important in the germination of spores (Halvorson \& Church, 1957). The fact that intact spores rapidly catalyse the racemization of alanine (Stewart \& Halvorson, 1953) and the deamination of adenosine (Powell \& Hunter, 1956) indicates that the substrates have ready access to these enzymes; this would be afforded if these enzymes are located outside the spore coat. By contrast, the pyrophosphatase (Levinson, Sloan \& Hyatt, 1958) has no demonstrable activity in intact spores, and the activity of catalase (Murrell, 1955) is greatly increased by disruption.

After stripping the spore body of the exosporium, the naked spore is still viable and heat resistant. Preliminary experiments have indicated that the thermal death rate and the germination requirements are not greatly altered by stripping the spores. In a sense the exosporium is like the capsule of a bacterium, in that it is not essential for viability. Unlike the capsule, however, the exosporium contains enzymes which play an active part in the metabolism of the spore.

Racemase and deaminase are heat-resistant in the exosporium and after release as particulate enzymes. After conversion to a form which does not sediment in high-speed centrifugation, both enzymes become more sensitive to heating, particularly the deaminase, in agreement with the findings of Stewart \& Halvorson (1954) and Powell \& Hunter (1956). It seems unlikely that the heat resistance of those external enzymes is related to the heat 
resistance of the spore proper but rather is conferred by the particulate complex which contains the enzyme. The heat resistance of ribosidase, which was found in the spore coat, also appears to be independent of the integrity of the spore (Powell \& Hunter, 1956). The pyrophosphatase and catalase, which appear to be inside the spore body, are not destroyed by heating the intact spore but are destroyed by heating crushed spores (Levinson, Sloan \& Hyatt, 1958; Murrell, 1955). These enzymes may be protected from heat by a different mechanism.

Sonic treatment is probably not the method of choice in the disruption of spores. Although it offers the advantage of the selective removal of the exosporium before disruption, the rate constant for disruption of the spore body is low, only $0.013 \mathrm{~min}^{-1}$ for Bacillus cereus 2005 and less than $0.003 \mathrm{~min}^{-1}$ for B. cereus var. terminalis. During the long treatment necessary to disrupt a significant fraction of the spores the emptied spore coats are comminuted to submicroscopic particles. In this respect sonic treatment resembles disruption with the Hughes press (Murrell, 1955). In contrast, the disruption by shaking with glass beads yields an appreciable quantity of empty spore coats (Murrell, 1955; Powell \& Hunter, 1956). Sonic treatment to remove the exosporium followed by disruption of the naked spore body by shaking with glass beads would permit a resolution of the constituents from the exosporium, the spore coat, and the interior of the spore.

This work was supported by a grant from the National Science Foundation, an agency of the United States Government. We wish to thank Dr L. R. Berger for the analysis of samples for hexosamine and Mr J. Pangborn for his assistance in electron microscopy.

\section{REFERENCES}

Bergen, L. R. \& ReYnolds, D. M. (1958). The chitinase system of a strain of Streptomyces griseus. Biochim. biophys. Acta. 29, 522.

Halvonson, H. O. \& ChurCh, B. (1957). Biochemistry of spores of aerobic bacilli with special reference to germination. Bact. Rev. 21, 112.

Levinson, H. S., Sloan, J. D. \& Hyatt, M. T. (1958). Pyrophosphatase activity of Bacillus megaterium spore and vegetative cell extracts. J. Bact. 75, 291.

Marr, A. G. \& Cota-Robles, E. H. (1957). Sonic disruption of Azotobacter vinelandii. J. Bact. 74, 79.

Murrelu, W. G. (1955). The Bacterial Endospore. Monograph published by the University of Sidney, Australia.

Negruern, E. \& Brömel, H. (1938). Protein der d-Aminosäureoxydase. Biochem. Z. 300, 225.

Powem, J. \& Hunter, J. R. (1956). Adenosine deaminase and ribosidase in spores of Bacillus cereus. Biochem. J. 62, 381 .

RoBINow, C. F. (1951). Observations on the structure of Bacillus spores. J. gen. Microbiol. 5, 439.

Robrnow, C. F. (1958). Spore structure as revealed by thin sections. J. Bact. 66, 800.

Stewart, B. T. \& Halvongon, H. O. (1953). Studies on the spores of aerobic bacteria. I. The occurrence of alanine racemase. J. Bact. $65,160$.

Stewart, B. T. \& Halvorson, H. O. (1954). Studies on the spores of aerobic bacteria. II. The properties of an extracted heat stable enzyme. Arch. Biochem. Biophys. 49, 168. 
Journal of General Microbiology, Vol. 22, No. 1
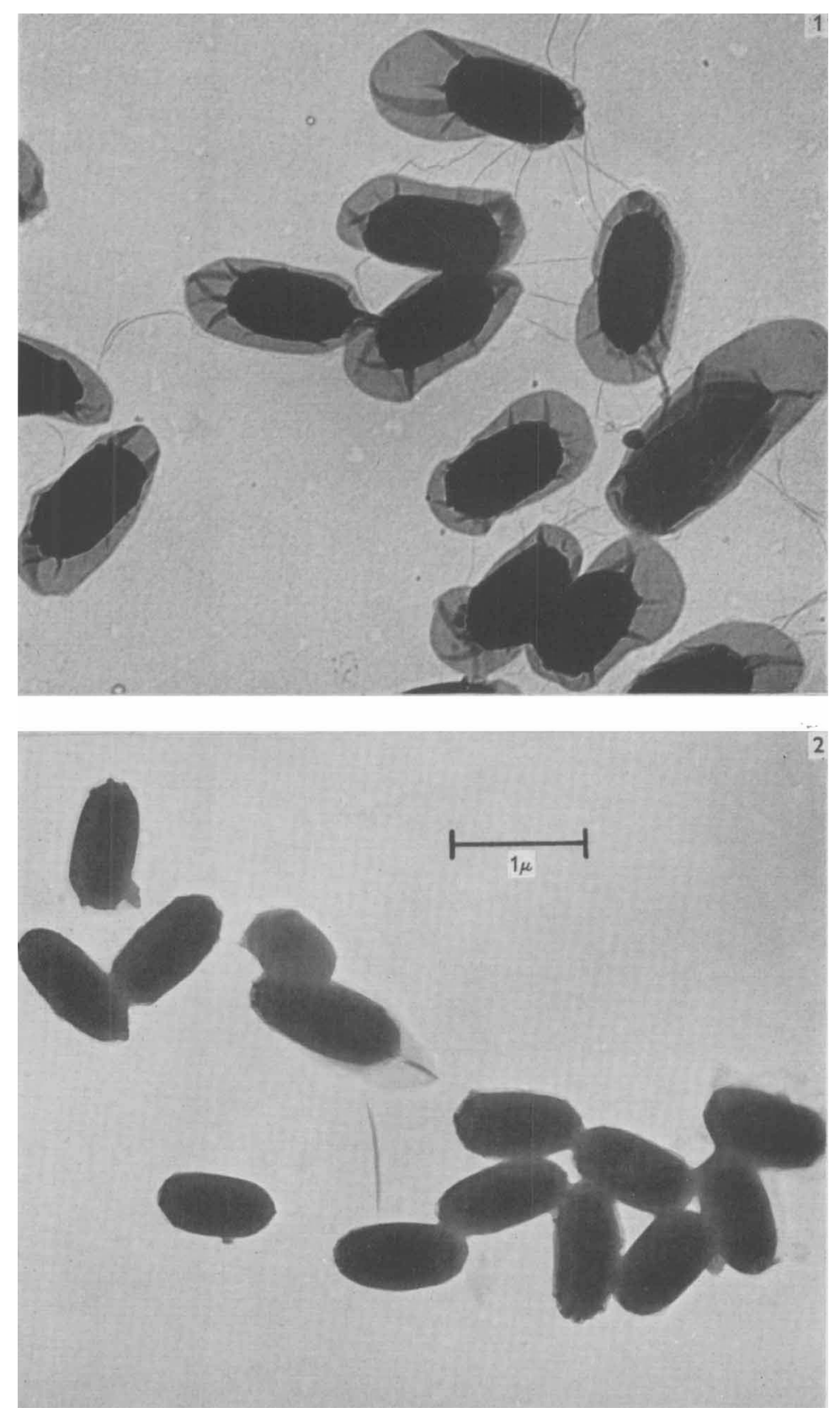

J. A. Berger \& A. G. Mark-Disruption of spones. Plate 1 
Journal of General Microbiology, Vol. 22, No. 1
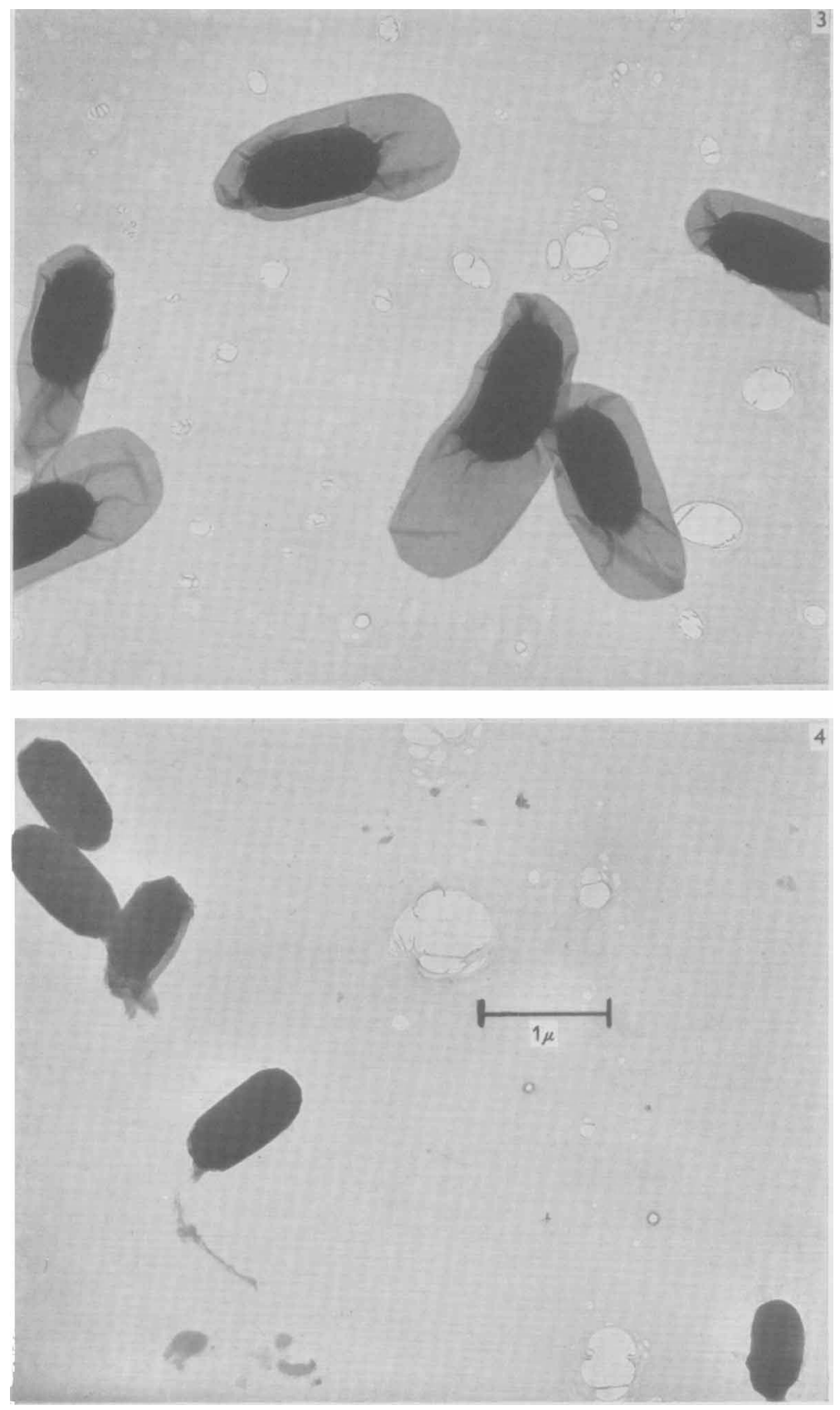

J. A. Berger \& A. G. Marr-Disruption of spores. Plate 2

$\therefore$ 


\section{EXPLANATION OF PLATES}

Plate 1. Electron micrographs of spores of Bacillus cereus 2005

Fig. 1. Before sonic treatment.

Fig. 2. After sonic treatment for $1 \mathrm{hr}$. The exosporium is the almost transparent envelope surrounding the dense spore body.

Plate 2. Flectron micrographs of spores of Bacillus cereus var. terminalis

Fig. 8. Before sonic treatment.

Fig. 4. After sonic treatment for $2 \mathrm{hr}$.

(Received 7 July 1959) 